\title{
The role of structural inheritance in oblique rifting: insights from analogue models and application to the Gulf of Aden
}

\author{
Julia Autin (1), Nicolas Bellahsen (2), Sylvie Leroy (2), Laurent Husson (3,4), Marie-Odile
} Beslier (5) and Elia d'Acremont (2)

(1) IPGS - UMR 7516; Université de Strasbourg/EOST, CNRS ; 1 rue Blessig 67084

Strasbourg, France - autin@unistra.fr - 0033 (0)368850480 - fax: 0033 (0)368850402

(2) Univ. Pierre et Marie Curie, iSTeP UMR 7193 UPMC-CNRS, 4 place Jussieu, Case 129, T46-00, 2ème étage, 75252 Paris cedex 05, France

(3) Université Rennes 1, CNRS UMR 6118, Géosciences Rennes, Rennes, France

(4) Université de Nantes, CNRS UMR 6112, LPG Nantes, Nantes, France

(5) Université de Nice Sophia-Antipolis, CNRS (UMR 7329), Observatoire de la Côte d'Azur, Géoazur, BP48, 06235 Villefranche-sur-Mer cedex, France

\section{Highlights}

We performed analogue models of oblique rifting with structural inheritance.

Structural inheritance is preponderant in the development of oblique rifts.

Previous rifting events may have more influence than oblique lithospheric weakness.

Inheritance initiates shifted spreading centres and transform zones or margins.

The models are used to understand the evolution of the Gulf of Aden oblique rift.

\section{Abstract}

The geometry and kinematics of rifts are strongly controlled by pre-existing structures that may be present in both the crust and the mantle lithosphere. In the Gulf of Aden, the Tertiary oblique rift developed through inherited Mesozoic extensional basins that trend orthogonal to the direction of Oligo-Miocene divergence. Such inheritance may produce lateral variations in crustal thickness and thus in rheology of the crust and mantle lithosphere. How can such variations influence the present-day geometry of oblique rifts? May they locally overcome the impact of the oblique rheological weaknesses that in 
certain cases control the overall trend of the rift system? Moreover, we observe that major fracture zones systematically crosscut the inherited basins: may such inheritance influence the localization of major fracture zones by shifting the initial spreading centers?

The brittle-ductile multilayer analogue models presented in this contribution reproduce oblique rifts. We tested the effect of an initial oblique weakness in the lithospheric mantle (i.e. structural or thermal inheritance) by introducing an oblique rheological weakness, which is alternatively initially imposed or dismissed. We tested the effect of the orthogonal Mesozoic inheritance by adding an elongated thicker brittle mantle, orthogonal to the direction of extension, in two models. These models mainly show en-échelon patterns with orthogonal faults and few rift-parallel faults (parallel to the rift obliquity), suggesting that the inherited orthogonal discontinuity is more influential than the oblique weakness in the lithospheric mantle.

These results suggest that the presence in the lithosphere of an inherited basin could constitute a barrier to the deformation and sufficiently offset the spreading centers to lead to independent rift systems separated by major fracture faults. Moreover, the genetic nature of the obliquity (boundaries-driven or inherited) could control the length of the transform offset between two spreading centers and thus, the length of the future transform margin (continental domain affected by a transform fault).

\section{Introduction}

Structural inheritance is a key factor to understand the tectonic evolution and structural deformation pattern of the lithosphere. In particular, successive rifting events often occurred in regions where oceanic crust is now forming. The multiple rifting events may have the same kinematics (rift and divergence trends) [e.g. Gop rift, Armitage et al., 2010] or different ones [e.g. Vøring margin, Talwani and Eldholm, 1972]. In the specific case of 
oblique rifting, the rift trend may be inherited from a previous orthogonal rift stage [e.g. the Northern Main Ethiopian Rift, Bonini et al., 1997; Wolfenden et al., 2004]. Yet, oblique rifts are not always related to pre-structured lithospheres and they can develop as a result of both specific far-field stresses and local weaknesses that define a segment oblique to the far-field divergence [e.g. Gulf of Aden, Bellahsen et al., 2003, 2006]. For example, no evidence for oblique pre-rift structuration is found in the Gulf of Aden and no weakness parallel to the Gulf trend is recognized in the geological record. However, a group of $\mathrm{N} 130^{\circ} \mathrm{E}, \mathrm{N} 110^{\circ} \mathrm{E}$ and $\mathrm{N} 90^{\circ} \mathrm{E}-$ oriented Mesozoic (Jurassic to Cretaceous) basins trend sub-orthogonal to the far-field divergence $\left(020^{\circ} \mathrm{E}\right)$ that prevailed during oblique rifting. They became partially reactivated during the Tertiary episode of oblique rifting [Ellis et al., 1996; Granath, 2001; Leroy et al., 2012; Fig. 1]. While the Mesozoic structuration trends mainly orthogonally $\left(110^{\circ} \mathrm{E}\right)$ to the Tertiary extension direction, the Tertiary Gulf of Aden developed with an oblique trend $\left(075^{\circ} \mathrm{E}\right)$. This observation could indicate that the Mesozoic inheritance had no influence on the rift obliquity. Conversely, the fact that the Mesozoic basin-bounding structures were locally reactivated along the oblique trend of the rift seemingly indicates that they play a role in the development of the Tertiary rift. It is also proposed that their reactivation could have controlled the strong margin asymmetry in the Eastern Gulf of Aden [D’Acremont et al., 2005, 2006]. Moreover, the largest inherited basins appear to be cut by first order fracture zones (Fig.1). The main example is the Jiza-Qamar-Gardafui basin, which is cut by the AlulaFartak Fracture Zone (AFFZ on Fig. 1). These observations suggest that inherited basins could control at least partly the present-day geometry of an oblique rift and, in particular, the localization of major fracture zones that segment the Gulf of Aden.

A variety of analogue models have been used to interpret the geometry and evolution of oblique rifts [e.g. Withjack and Jamison, 1986; Tron and Brun, 1991; Dauteuil and Brun, 
1993; McClay and White, 1995; Abelson and Agnon, 1997; Bonini et al., 1997; Mart and Dauteuil, 2000; Clifton et al., 2000; Dauteuil et al., 2001; Clifton and Schlische, 2001; Corti et al., 2001, 2003, 2011; Agostini et al., 2009; Autin et al., 2010a; review of Corti, 2012]. Moreover, recent results from numerical models [Brune et al., 2012] show that oblique extension significantly facilitates the rift process, as oblique deformation requires less force in order to reach the plastic yield limit than rift-perpendicular extension. These results emphasize the importance of understanding the significance of oblique extension processes for the development of rifted margins. In this study, we use analogue models to explore the interaction of oblique rifting with orthogonal inherited basins. Rift obliquity is alternatively forced by the lateral discontinuities in the model or by the combination of lateral discontinuities with an oblique weakness. We compare these results with a previous set of analogue models of oblique rifting without orthogonal inheritance [Autin et al., 2010a]. Finally, we infer (1) the influence of the inherited basins on the development of the Gulf of Aden, (2) the localizing effect of inherited basins on fracture zones and thus transform margins, and (3) how the genetic nature of the obliquity (boundaries-driven or inherited) influences the transform fault geometry.

\section{Geological setting}

The Gulf of Aden trends $075^{\circ} \mathrm{E}$ and is oblique to the main direction of divergence $\left[025^{\circ} \mathrm{E}\right.$ to $035^{\circ} \mathrm{E}$ from East to West, Jestin et al., 1994; Vigny et al., 2006]. Along the entire Gulf, rifting started at about 34 Ma [Roger et al., 1989; Jestin et al., 1994; Robinet et al., 2013]. At this time, the subduction of Tethyan slabs underneath the Eurasian plates was blocked in the West where collision occurred, whereas it was going on in the East [Bellahsen et al., 2003]. This configuration combined with the Afar hot spot [45 Ma with main pulses at ca. 30 Ma, Hofmann et al., 1997; Ebinger and Sleep, 1998; George et al., 
1998; Kenea et al., 2001] produced oblique rifts, whose geometries cannot be attributed to any preexisting lithospheric weakness [Bellahsen et al., 2003, 2006; Autin et al., 2010a]. The Afar hot spot is still active, as attested by present volcanic activity in the Afar area, by Quaternary volcanics along the Yemeni margins [Leroy et al., 2010b], and by shallower bathymetry and higher heat flow toward the West of the Gulf [Lucazeau et al., 2010; Rolandone et al., 2013]. Moreover, melting anomalies and ridge jumps along the Sheba Ridge may also indicate that the hot spot melt and heat could have been channelized along the Aden Ridge [Fig. 1, d'Acremont et al., 2010; Leroy et al., 2010b]. The spreading started at 17.6 Ma between Shukra El Sheik Fracture Zone (SSFZ) and the Africa-Arabia Shelf [Fig. 1, D’Acremont et al., 2006; Leroy et al., 2012], at 6 Ma West of SSFZ [Audin et al., 2004] and at $20 \mathrm{Ma}$ in the extreme eastern part [Fournier et al., 2010]. The structural pattern in the whole Gulf is strongly controlled by Mesozoic inherited basins with trends between $90^{\circ} \mathrm{E}$ and $140^{\circ} \mathrm{E}$ [see Birse et al., 1997; Brannan et al., 1997; Leroy et al., 2012 for a synthesis]. Mesozoic rifting started in Late Jurassic with an increase of the subsidence eastward during Late Jurassic-Early Cretaceous [Bott et al., 1992; Beydoun et al., 1996]. Therefore, the Mesozoic sediment thickness increases eastward from 1.8 to $6 \mathrm{~km}$ [As-Saruri et al., 2010]. These basins were partly reactivated during the oblique Tertiary rifting and their reactivated parts are consequently arranged en-échelon along the passive margins (Fig. 1). In the final evolution of distal margins, deformation commonly became localized in the thinnest areas, close to the future oceancontinent transition (OCT). In the eastern Gulf of Aden, serpentinized mantle may be exhumed in the OCT and locally intruded by post-rift magmatic material [D'Acremont et al., 2006; Autin et al., 2010b; Watremez et al., 2011], which could have been channelized from the Afar hot spot along the oceanic ridge and the Alula-Fartak Fracture Zone and transform margin [Leroy et al., 2010b]. We thus need to better understand how such large 
scale transform margin forms to study the interaction beween magma, ridge, fracture zone and transform margin in the Eastern Gulf of Aden.

\section{Model setup}

\subsection{Model setup, materials and scaling}

The models were constructed in a deforming box (initial dimensions: $56 \times 30 \times 30 \mathrm{~cm}$; Fig. 2) consisting of a bottomless drawer sliding in a rectangular box. In our model setup, the drawer is pulled by a motor-driven screw jack, which sets the direction of divergence. The different lengths of the drawer arms create two lateral discontinuities, imposing that the trend of deformation is overall oblique (Fig. 2).

Extending continental lithospheres with average crustal thickness (about $35 \mathrm{~km}$ ) and geotherm behaves as a brittle-ductile multilayer [Kirby, 1983], which can be described in terms of a four-layer type strength profile [Davy and Cobbold, 1988, 1991]. In the laboratory, such a multilayer is modeled using granular materials and silicone. Here, we used a microsphere mix (composed of $4 / 5$ glass to $1 / 5$ hollow aluminum microspheres) and silicone putty as analogues of brittle and ductile layers respectively.

Upon this simplification, our models represent the oblique extension of a strong lithosphere as observed in cratons (in terms of strength not of thickness), and as such they consist of an brittle upper crust, a ductile lower crust, a brittle lithospheric mantle and a ductile lithospheric mantle (see Fig. 2 and Table 1 for details). The modeled lithosphere overlies a low viscosity, higher density glucose syrup that mimics the asthenosphere.

Thicknesses, viscosities, densities and strain rates were appropriately scaled to simulate an extending continental lithosphere in the ambient gravity field. The description of the material used in these models as well as the complete scaling calculation can be found in Autin et al. [2010a]. $1 \mathrm{~cm}$ in the experimental model corresponds to $13 \mathrm{~km}$ in nature; 
1 experimental hour corresponds to $0.85 \mathrm{Ma}$ in nature. The experiments were performed with an extension velocity of $\mathrm{V}=5 \mathrm{~cm} / \mathrm{h}$. In the fast range of rifting processes, this velocity, which corresponds to about $6 \mathrm{~cm} / \mathrm{yr}$ in nature, is comparable to velocities applied in previous studies, as is the rheology of the model used here [McClay and White, 1995; Benes and Davy, 1996; Brun and Beslier, 1996; Sokoutis et al., 2007].

\subsection{Experiments}

The initial rheology and scaling of the models aim to represent the strong lithosphere, in which the Gulf of Aden formed (Arabian Craton). As no thermal effects can be introduced in the analog models, the impact of the Afar hot spot cannot be reproduced. However, the hot spot should have weakened the adjacent lithosphere and thus the weaker models could represent hotter settings, even if they do not include the hot spot itself. The models aim to investigate (1) the role of orthogonal inheritance on the oblique rift and transform margins development (2) the influence of the genetic nature of the obliquity on the rift geometry.

(1) We considered that a Mesozoic inherited basin constitutes a rheological hardness. Indeed, the Mesozoic rifting took place more than $30 \mathrm{Ma}$ prior to Tertiary oblique rifting. Thus, the upwelling lithospheric mantle, which then cools, should be thicker than the nonstretched surrounding mantle [e.g. van Wijk and Cloetingh, 2002]. The rheological impact of such inheritance would thus consist in zones of stronger lithosphere, expected to localize the deformation at their edges. The influence of the Afar hot spot occurred after the Mesozoic lithosphere cooling.

(2) The rift obliquity could either be produced by an oblique inheritance (inherited obliquity) or by plate boundaries effects on the initially homogeneous lithosphere (boundaries-driven obliquity). In the models (Fig. 2), we choose to model both types of obliquity. The obliquity is either forced by the modelled lateral discontinuities alone (boundaries-driven obliquity) or by the combination of lateral discontinuities with an 
oblique weakness (mainly reproducing an inherited obliquity). This oblique weakness could either represent geological inheritance or a localized thermal weakening of the lithosphere by the adjacent Afar hot spot in the West (and possibly the Carlsberg ridge in the East).

In this frame, we have elaborated four configurations of oblique extension (Fig. 2c):

(a) an experiment with a stratified lithosphere of initially uniformly thick layers (model A), where obliquity is only induced by lateral discontinuities. It represents a rift with a boundaries-driven obliquity and no orthogonal inheritance;

(b) an experiment with a strong orthogonal hardness (model B). It consists of a locally thicker lithospheric brittle mantle designed prior to the experiment $(1 \mathrm{~cm}$ thick instead of $0.8 \mathrm{~cm}$, along a $2 \mathrm{~cm}$-wide zone, i.e. $26 \mathrm{~km}$ in nature). The model represents a rift with a boundaries-driven obliquity and orthogonal inheritance;

(c) an experiment where a weakness zone trends parallel to the direction of obliquity imposed by the lateral discontinuities and joins them (model C). The weakness zone consists of a locally thinner lithospheric brittle mantle designed prior to the experiment (a thickness of $0.6 \mathrm{~cm}$ instead of $0.8 \mathrm{~cm}$ along a $5 \mathrm{~mm}$-wide zone). The model represents a rift with inherited obliquity and no orthogonal inheritance;

(d) an experiment with both the oblique weakness zone and the orthogonal hardness zone (model D). It represents a rift with inherited obliquity and orthogonal inheritance.

The Gulf of Aden trends $075^{\circ} \mathrm{E}$ with a far-field divergence trending $025^{\circ} \mathrm{E}$. Thus, the obliquity, i.e., the angle between the direction of far-field extension and the normal to the rift trend, is $40^{\circ}$ and is the same in all models. The total displacement is $10 \mathrm{~cm}$ in all experiments, corresponding to an average extension of $20 \%$ throughout the entire model that focuses to 150 to $200 \%$ within the rift. For technical simplicity, but also in order to 
fully observe the fault patterns, no extra sedimentation was applied during the experiments, since this tends to be an obstacle to clear identification of fault activity from the surface. This was achieved by comparing top-view photographs and scanned topography at successive steps of the experiment. Thermal effects or rheological changes occurring during rifting are not modeled in these experiments.

Models that do not account for an orthogonal hardness zone (model A and C) were already studied in Autin et al. [2010a]. Thus, the present contribution will not focus on their development, but on the development of the models that take orthogonal prestructuration into account (models B and D). Models A and C led us to propose, in a previous study, that the Eastern Gulf of Aden would have rather developed in the absence of an oblique, rift-parallel weakness.

\section{Results}

In our previous study [Autin et al., 2010a], 3 main fault populations were observed that show different angles $(\theta)$ between the direction of divergence $\left(\theta=0^{\circ}\right)$ and the trend of the fault (Fig. 3). These are: (1) $\theta \sim 50^{\circ}$ : rift-parallel faults, (2) $\theta \sim 70^{\circ}$ : intermediate faults, (3) $\theta \sim 90^{\circ}$ : divergence-normal faults (e.g. orthogonal). We apply the same terminology in this study.

4.1. Influence of extension-perpendicular crustal hardening in the case of no lithospheric oblique weakness

A first approach is to compare the evolution of the models with or without orthogonal hardness, but without the effect of an oblique weakness (model A and B respectively, Fig. 3a and Fig. 3b). Model A serves as the reference model, wherein no hardening nor oblique lithospheric weakening is imposed and the deformation initiates close to the lateral discontinuities with an intermediate fault direction (2.5\% extension, Fig. 3a). The ongoing deformation leads to the propagation of the 2 lateral deformation zones by en- 
échelon intermediate-oriented grabens. But, in the center of the model, the connection between these zones is formed by rift-parallel faults ( $4 \%$ extension). Then, deformation is limited to the existing grabens. They widen and deepen and new faults appear in the existing grabens (6.5 and $10 \%$ extension). Clockwise rotations $\left(>20^{\circ}\right)$ affect the structures and initially intermediate-oriented horsts become divergence-normal at $10-16 \%$ extension. The final development of the model (16 to $21 \%$ extension) shows numerous newly created divergence-normal faults located in the deepest parts of the most extended grabens.

By comparison, model B is globally similar but with few notable differences in the evolution of the deformation. The presence of the orthogonal hardness is observable from the very beginning of development. Two grabens with an intermediate direction localize on the orthogonal hardness $(2.5 \%$ extension, Fig. $3 \mathrm{~b}$ and Fig. $4 \mathrm{a})$. The subsequent deformation is localized in the 2 grabens until $3 \%$ extension. Then, deformation becomes more distributed when new en-échelon intermediate grabens develop to link the lateral discontinuities with the central grabens (4\% extension). Rift-parallel faults are located at the extremities of the intermediate grabens all along the rift. The deeper central grabens prevents the lateral propagation of the deformation. Then, as for model A, the deformation is limited to the existing grabens. At $10.5 \%$ extension, the deformation is almost the same in each grabens of the model, showing that deformation is no more localized in the initial central grabens. Clockwise rotations of the structures (up to $50^{\circ}$ ) are even greater than in model A $\left(>20^{\circ}\right)$, rotating initially intermediate horsts $\left(\theta \sim 70^{\circ}\right)$ to a $\theta \sim 120^{\circ}$ position at 23 $\%$ extension (e.g. Fig. 4a, grabens marked by the red dots and the horst in between). This rotation is similar to the one affecting the orthogonal hardness $\left(44^{\circ}\right)$ from $\theta \sim 90^{\circ}$ to $\theta \sim 134^{\circ}$ (Fig. 5b). The final development of the model (16.5 to $23 \%$ ) shows also numerous newly created divergence-normal faults located in the deepest parts of the most extended grabens 
(Fig. 4 and Fig. 5).

\subsection{Role of the oblique lithospheric weakness with extension-perpendicular hardening}

In a second approach, we analyze the evolution of the models without or with orthogonal hardening, in lithospheres with an initial oblique weakness (model C and D, respectively, Fig. 3c and Fig. 3d). Model $\mathrm{C}$ initiates with en-échelon intermediate grabens all along the rift. They are distributed along two oblique areas on both sides of the pre-existing oblique weakness $(2.5 \%$ extension, Fig. $3 \mathrm{c})$. From this early stage, the deformation is limited to the existing grabens. The ongoing deformation widens and deepens the grabens. Riftparallel faults join the intermediate grabens, which individualize one continuous central horst in the rift center, above the initial oblique weakness (4 and $7 \%$ extension). At $10.5 \%$ extension, the central horst starts to be cut by rift-parallel to intermediate faults, whereas divergence-normal faults are created in the deepest parts of the most extended grabens (16.5 to $19.5 \%$ extension). From its initiation to the end of the experiment, the central horst and the lateral grabens undergo a clockwise rotation of $8^{\circ}$, which is much less than the rotation displayed by the models without oblique weakness (models A and B).

By comparison, model D, which includes the divergence-orthogonal hardness, shows another pattern of deformation. The initial stage of deformation is similar to model $\mathrm{C}$ with en-échelon intermediate grabens all along the rift on both sides of the oblique weakness (2.5\% extension, Fig. $3 \mathrm{~d})$. Three central grabens (instead of 2 in model B) develop on the pre-existing orthogonal hardness (2.5\% extension on Fig. $4 \mathrm{~b}$ and Fig. $5 \mathrm{~d})$. They have an intermediate to divergence-normal trend. Two of them develop on the left side of the weakness and one on the right side. Contrarily to model B, these central grabens do not prevent the lateral propagation of deformation. Rift-parallel faults form at the extremities of the intermediate grabens and individualize an oblique central horst. Yet, this horst is 
more segmented than in model C (Fig. 3d, 4 and 7\% extension). Afterward, no new structures are created outside the existing grabens, where the deformation localizes. On both sides of the central horst, the grabens link to form a major intermediate zone of deformation at $10.5 \%$ extension. From 9.5 to $22.5 \%$ extension, this large graben rotates from intermediate to divergence-normal with a clockwise motion (24․, Fig. 4b). Divergence-normal faults are created in the deepest parts of the most extended grabens.

It is noteworthy that the differences between models $\mathrm{C}$ and $\mathrm{D}$ (inherited obliquity) are much more important than differences between models $\mathrm{A}$ and $\mathrm{B}$ (boundaries-driven obliquity). In other words, the divergence hardness has a stronger role in presence of an oblique inherited weakness.

\subsection{Location and evolution of the main thinning areas}

In such multilayer models, the most resistant part of the lithosphere is the brittle mantle (Fig. 2b). We thus consider that the low thickness of the brittle mantle (top view in Fig. 6 and thickness in Fig. 7) provides evidence for significant thinning of the lithosphere. The thinnest part coincides with the most stretched part of the sand layer. This deformation can be compared to the pattern of the upper crust deformation (Fig. 6b) and the whole crust thickness (Fig. 7). In four-layer analogue models [e.g. Brun and Beslier, 1996], the thinning of the two brittle layers does not occur at the same place: where a graben is observed in the brittle crust, a brittle mantle horst is present at depth. This is explained by the offset between brittle crust and brittle mantle structures being accommodated by lowangle shear zones in the intermediate ductile crust [see Brun and Beslier, 1996].

In model $\mathrm{A}$, the deepest areas of the brittle mantle have a right-stepping en-échelon divergence-normal disposition, which indicates rather distributed horizontal deformation throughout the entire model (Fig. 6a). In model B (orthogonal mantle hardening), the main thinning areas in the mantle are disposed on both sides of the band of thick brittle mantle 
$\left(120^{\circ}\right.$-oriented). The thinnest parts are not located in the rift center but close to the hardness inflection points (circles on Fig. 7). It is noteworthy that models A and B locally show areas where the thinned brittle crust and the thinned brittle mantle are superimposed with crossed directions (Fig. $6 \mathrm{~b}$, point P). They may result from large rotations $\left(50^{\circ}\right.$ in model B, red dots grabens in Fig. 4a). Indeed, the rotation of the structures leads to an overprinting of the deformation: thinned areas were formed when the structures had an intermediate direction, then the structures rotated and a new thinned area started to develop in a divergence-normal direction.

In model C (oblique weakness), the brittle mantle is extremely thinned (oblique breakup of the brittle mantle, Fig. 6a). The thinning area is oblique and corresponds to the location of the oblique weakness. The deformation localizes on the weakness zone and leads to the breakup of the brittle mantle.

In model D (both orthogonal hardening and oblique weakness), the deepest brittle mantle topography is in the center of the rift (Fig. 6a). This area has a divergence-normal direction and crosses the oblique weakness. The first order deformation shows a divergence-normal direction of the deformation in both the brittle crust and brittle mantle (Fig. 6b). Nevertheless, the deepest areas of the brittle mantle (Fig. 6) do not correspond to the thinnest brittle mantle (Fig. 7). Indeed, the relative thickness of the brittle mantle shows that the thinnest areas are not located in the rift center but near both inflection points of the mantle hardness under the rift margins (circles on Fig. 7), as in model B.

To summarize, at final stages, the model with uniformly thick lithospheric layers (model A) shows distributed divergence-normal deformation whereas the model with oblique weakness alone (model C) localizes the deformation obliquely. The models with hardnesses (models B and D) localizes the deformation along the hardness and particularly close to its inflection points (circles on Fig. 7). This suggests again that the 
hardness prevents the lateral propagation of deformation, at least in the brittle mantle, accumulating it along its borders.

\section{Discussion}

\subsection{Reactivation of the orthogonal hardness}

In these analogue models, we interpret the structures that develop above the initial hardness zone as reactivation of previous structures. Of course, for technical reasons due to our modeling approach, this reactivation does not strictly consider inherited faults but only the deep pre-structuration of the lithosphere strengthened by previous crustal thinning and subsequent cooling. In the models that account for what we now refer to as "Mesozoic inheritance" (models B and D, Fig. 3b and Fig. 3d), some grabens are reactivated at the beginning of the deformation. In both cases, they trend at an intermediate direction in between the divergence-perpendicular trend and the rift trend. It suggests that their trend is not only controlled by the hardness (and the resulting strength contrast) but also by the rift obliquity. Actually, in the earliest stages, it seems that the hardness controls only the locations of the faults, their trend being controlled by the rift obliquity (Fig. 3 and Fig. 5).

In a more realistic setting however [with preexisting faults such as in Bellahsen and Daniel, 2005], the preexisting inherited divergence-normal faults would have been reactivated instead of creating intermediate faults and we can imagine that the inherited basins would have been reactivated in transtension.

The evolution of the reactivated basins depends on whether the obliquity is boundarydriven or inherited (i.e. absence or presence of an initial oblique weakness, Fig. 4). In model B (boundaries-driven obliquity), the reactivated grabens are located along the orthogonal inheritance with an intermediate trend (Fig. 4a). Nevertheless, the reactivated 
grabens prevent the lateral propagation of the deformation and they accommodate most of the displacement. The hardness prevents the development of rift-parallel faults $\left(\theta \sim 50^{\circ}\right)$ in the center of the model, which are characteristic of the oblique evolution observed in model A (Fig. 3a at 4\% extension). Rift-parallel faults localize in between en-échelon intermediate grabens where they seem to correspond to transfer zones rather than normal faults (no associated subsidence, Fig. $3 \mathrm{~b}$ at 4 and $7 \%$ extension). Thus, it seems that the inheritance favors the en-échelon pattern of deformation over oblique structures. With continuing extension a divergence-perpendicular deformation belt is formed, separating the northern and southern parts of the rift and, due to clockwise roation, the deformation belt becomes almost perpendicular to the rift axis, above the sigmoid hardness (Fig. $5 b$ ). Then, the reactivated grabens located in the belt propagate laterally but remain separated by a large horst (Fig. 4a at 23\% extension). Their final position shows a left-stepping enéchelon pattern.

In model D (inherited obliquity), three reactivated grabens are formed: two are located on the left side of the oblique weakness zone and one on the right side (Fig. $4 \mathrm{~b}$ and Fig. $5 \mathrm{~d})$. They develop later ( $2.5 \%$ extension) than in model B ( $1.5 \%$ extension). It seems that the oblique weakness delays the reactivation of the grabens. They are not initially aligned, as the graben located on the right side of the weakness remains separated from the other two by a large horst, which develops initially on the oblique weakness. The two grabens on the left side link together (and with a newly formed graben) to form the major obliquely thinned area of the brittle crust (Fig. 7). Thus, the oblique weakness has a strong influence on the reactivation since it separates two domains of deformation. Moreover, the reactivated grabens are used to create an oblique structure, which then will rotate in a divergence-normal position (Fig. $4 \mathrm{~b}$ at $9.5 \%$ extension).

Consequently, the final disposition of the reactivated grabens shows an en-échelon 
pattern in model $\mathrm{B}$, whereas model $\mathrm{D}$ shows an alignment of the reactivated basins accompanied by a strong rotation (from an oblique trend to a divergence-normal trend). Thus, in oblique settings, the way inherited basins are reactivated may be strongly dependent on the origin of the obliquity.

\subsection{Orthogonal hardening vs. oblique weakness}

The observation of model $\mathrm{C}$ indicates that the oblique weakness strongly influences the development of oblique areas of major deformation (Fig. 5c). Moreover, it even induces the oblique breakup of the brittle mantle (no more material on Fig. 6a), i.e. the most resistant layer of the modelled lithosphere (Fig. 1). The "reactivation" of the inherited oblique weakness is thus very efficient. Model B shows the influence of the orthogonal inheritance, which strongly localizes the deformation in an E-W belt and where reactivation is located in en-échelon grabens (Fig. 4a, red dots). The final thinning of the brittle mantle occurs along divergence-normal en-échelon zones (Fig. 6b). It is noteworthy that rotations in models that do account for orthogonal inheritance $\left(44^{\circ}\right.$ in model $\mathrm{B}, 24^{\circ}$ in model D) are always larger than in models that ignore it $\left(20^{\circ}\right.$ in model $\mathrm{A}, 8^{\circ}$ in model C), suggesting that the hardness zone rotates because it resists deformation. Model D indicates that the influence of orthogonal inheritance conceals that of the oblique weakness. Indeed, oblique development of the deformation is less obvious than in model $\mathrm{C}$ either in the brittle crust or in the brittle mantle. Moreover, the initial central horsts, which were aligned along the initial weakness, rotate in a divergence-normal direction at the final stage, so that the influence of the oblique weakness is no longer visible (Fig. 4b and Fig. 5d). Oblique deformation is however present on the borders of the rift. One could argue that our analogue model of the orthogonal inheritance was unrealistically determinative. The $2 \mathrm{~cm}$ wide initial brittle mantle hardeness scales to a $27 \mathrm{~km}$-wide zone of deformation. The largest reactivated basin along the Gulf of Aden 
(Jiza-Qamar Basin) is $100 \mathrm{~km}$ wide after reactivation. If we consider that the Jiza-Qamar Basin underwent the improbable maximum stretching factor of 4 [for which the entire crust becomes brittle leading to mantle serpentinisation or strong magmatism, PérezGussinyé and Reston, 2001], the initial inherited basin would have been $25 \mathrm{~km}$ wide. This suggests that our model scales well with nature.

To summarize, according to our analogue models, the presence of an orthogonal inherited rift would promote the development of en-échelon patterns of deformation as well as important rotations, whereas an oblique weakness zone within the lithospheric mantle would localize the deformation in a narrower rift. Moreover, in the presence of both heterogeneities, it seems that the influence of orthogonal inheritance conceals that of the oblique weakness.

\subsection{Comparison with the Gulf of Aden}

\subsubsection{Model settings related to the Gulf of Aden features}

In a previous paper [Autin et al., 2010a], we argued that the Eastern Gulf of Aden is better reproduced by the model that initially has lithospheric layers with uniform thicknesses (model A) than by the one that accounts for oblique lithospheric weakening prior to extension (model C). This is supported by the absence of any observed oblique heterogeneity and the correspondence of the fault pattern and chronology [Lepvrier et al., 2002; Huchon and Khanbari, 2003; Fournier et al., 2004, 2007; D’Acremont et al., 2005; Bellahsen et al., 2006; Autin, 2008; Leroy et al., 2012] as well as the formation of displacement-parallel transfer zones. It implies that oblique rifts are not necessarily produced by an oblique weakness zone (inherited obliquity) but can result from two weakness points aligned obliquely compared to the displacement direction [boundariesdriven obliquity, e.g. Hubert-Ferrari et al., 2003]. Bellahsen et al. [2003] even suggest that one weakness point (Afar hot spot), with the specific far-field conditions resulting 
from the Tethys Ocean subduction, is enough to generate oblique rifts.

On the other hand, the influence of the Afar hot spot has undoubtedly weakened the lithosphere in the Western Gulf of Aden. The strong four-layer rheology used in our model is thus not representative of the Western Gulf of Aden. However, we propose that a first-order approach could be considered: models where the brittle mantle is thinner along the obliquity (models C and D) are weaker and thus they could be more representative of the western Gulf of Aden. Of course, this implies that the hot spot has weakened the lithosphere with a preferential direction, the one of the obliquity. This trend may have been controlled by the first thinning event, which displays the triple junction pattern of the Red Sea/Gulf of Aden/East African Rift. The trend can also be controlled by the alignment of the Afar hot spot in the West and the Carlsberg ridge in the East [HubertFerrari et al., 2003]. Moreover, Bellahsen et al. [this volume] propose that the buoyancy forces responsible for oblique structures are stronger in the Western part due to the warmer conditions imposed by the presence of the nearby Afar hot spot and plume connection (Fig. 8). Thus, these conditions could have produced a pattern similar to the one produced by an oblique lithospheric weakness.

Following this reasoning, we can propose, as a working hypothesis, that the oblique weakness introduced in model D could be similar to a lithosphere locally weakened by the Afar hot spot and thus this model would correspond to the Western Gulf of Aden with the reactivation of the Mesozoic Balhaf and Berbera Basins (Fig. 1), now shifted by the Khanshir Al Irquah Fracture Zone (KAFZ). On the other hand, model B (no oblique weakness zone) would better reproduce the influence of reactivated Mesozoic basins in the Eastern Gulf of Aden, where initial thermal weakening is probably absent. This setting corresponds to the Mesozoic Jiza-Qamar and Gardafui Basins (Fig. 1), now offset by the Alula-Fartak Fracture Zone (AFFZ). 
It is noteworthy that the influence of inheritance may be underestimated in the analog models. Indeed, in the Gulf of Aden, the Mesozoic sediment thickness reaches $6 \mathrm{~km}$, which corresponds to a thinning factor of 1.6 (37.5\% of thinning) after an estimation using the McKenzie model [1978]. In this model, for an initial crustal thickness of $40 \mathrm{~km}$, the calculated final thickness is $25 \mathrm{~km}$ with a Moho shallowing of $9 \mathrm{~km}$. In the models, we reduced the thickness of the layers representing the crust from 22 to $20 \mathrm{~mm}$ under the modelled inherited basin, i.e. a thinning factor of 1.1 (9.1\% thinning).

\subsubsection{Implications for the deformation of the Mesozoic Basins}

In the models, the final pattern corresponds to an advanced stage of rifting $(20 \%$ extension, i.e. a stretching factor of 1.25) before any crustal breakup, mantle exhumation or oceanic accretion. However, this pattern nicely show where the thinnest parts of the lithosphere would form at the late rift stage and eventually during breakup. Thus, the reactivated features in the models can be regarded as indicators of deformation that affected the Mesozoic basins from the onset of the Tertiary rifting to its end (before crustal breakup).

Surprisingly, the reactivated basins in both models C and D are not aligned but separated by horsts (Fig. 4). At depth, they localize above the best preserved parts of the hardness in the brittle mantle. Further connection between these basins is prevented by the strong rotations that affect both the rift center and the inherited hardness (see Fig. 4 and descriptions in part. 4.1 and 4.2). In natural setting the presence of divergence-normal faults would certainly have favored the alignment of the reactivated basins, in order to accommodate the transtension. Nevertheless, the rotations may have helped to connect them with newly formed grabens in the surroundings (Fig. 4, connection of red-dotted and blue-dotted grabens). These models highlight that a pre-existing basin will not necessarily be reactivated along its full length and not with its initial pattern: A single basin can be 
reactivated in two offset places that can experience rotations. Consequently, kinematic reconstructions in oblique settings should not tend to align the reactivated parts of the inherited basin but rather to restore the displacement induced by rotations during oblique rifting.

\subsubsection{Localizing effect of Mesozoic basins on future fracture zones}

As already stated, throughout the Gulf of Aden, all reactivated basins are offset by fracture zones. In the light of our models, we can propose that the presence of the inheritance could have localized the deformation and thus created contrasts in thickness, which could favor the emplacement of future transform zones (although they are not reproduced in the models) by initiating shifted spreading centers. Moreover, in both models $\mathrm{B}$ and $\mathrm{D}$, the inherited hardness is submitted to strong clockwise rotation, bending it into a sigmoid shape. We think that this movement could be the precursor of the rightlateral shift separating the conjugate margins of the oblique rift.

In the models, the strongest layer is the brittle mantle and thus, its thinning indicates the weakest part of the final rift. In model B, the thinnest parts of the brittle mantle (Fig. 7) follow the sigmoid shape on each side of the hardness zone. Moreover, it is even thinner toward the inflection points of the sigmoid. This suggests that the hardness prevents any further propagation of the deformation along the rift borders and localizes it along its boundaries and in particular in the narrow corners where the hardness zone meets the rift borders (circles on Fig. 7). Since rheological contrasts are known to localize effectively deformation, one can hypothesize that the stresses accumulate at the boundary between the thinned lithosphere and the stronger one, along the hardness. A similar localizing boundary exists where the thinned lithosphere is juxtaposed with the unthinned lithosphere on the rift borders at late stages of rifting. Both boundaries meet at the hardness inflection points. Following this hypothesis the weakest part of the lithosphere 
would localize in these corners, triggering the development of two independent spreading centers. In a numerical model [Brune and Autin, this volume], clockwise rotations are also observed and they finally lead to shear zones parallel to the divergence direction in the rift center. Thus, with further extension, further rotation of the hardness zone in the rift center would be expected and implies that these spreading centers would initiate with a rightlateral shift and would consequently require the development of a transform fault in between them (Fig. 9). In model D, we also observe stronger deformation along the inherited hardness and similar rotation and corner localization would lead to the initiation of shifted spreading centers. Nevertheless, the presence of the oblique weakness zone focuses the deformation in a narrower area, which would create closer spreading centers. This is compatible with natural observations: (1) In the Western Gulf of Aden, the deformation pattern is similar to models with an oblique weakness [Bellahsen et al., this volume] (Fig. 8) and the fracture zones moderately affect the continental domain $(<100 \mathrm{~km}$ along the KAFZ,), indicating relatively closely spaced spreading centers. (2) In the Eastern part, conversely, the deformation pattern is similar to models that ignore the oblique weakness zone and the spreading centers are widely spaced $(>200 \mathrm{~km}$ along the AFFZ,). (3) This evolution could explain the strong asymmetry observed between the conjugate margins of the Eastern Gulf of Aden. Indeed the southern margin is wider $(300 \mathrm{~km})$ than the northern margin $(140 \mathrm{~km})$ [D'Acremont et al., 2005, 2006]. These authors already proposed that inheritance causes the asymmetry by reactivation of the inherited basin. In our hypothesis, since the ridges localize close to the rift borders, it would also imply that (1) East of AFFZ, the largest part of the thinned continental domain is located on the Southern margin, between the OCT (red) and the Gardafui Basin; and (2) West of AFFZ, the northern continental margin should be wider, between the OCT and the Jiza-Qamar basin (Fig. 9). 


\section{Conclusion}

In these analogue models, we study the development of oblique rifting in a prestructured lithosphere (extension-orthogonal inherited basin), as well as the influence of the origin of obliquity (boundaries-driven or inherited).

Our modelling results suggest that the way inherited basins are reactivated may be strongly dependent on the way obliquity is constrained. This has implications for kinematic reconstructions as inherited basins can be reactivated in two offset locations that can experience strong rotations. We also propose that extension-orthogonal inherited basins promote the development of en-échelon patterns of deformation and important rotations about a vertical axis, whereas an initial oblique weakness zone within the lithospheric mantle would localize the deformation in a narrower rift. Moreover, in the presence of both types of heterogeneities (inherited basin and oblique weakness), it seems that the influence of orthogonal inheritance conceals that of the oblique weakness.

Comparing our results to the Gulf of Aden evolution suggests that reactivated basins could have favored the localization of future fracture zones (although not reproduced by our models). The inherited structure (hardness) is submitted to strong rotations and, at late stage of deformation, it acquires a sigmoid shape and cross-cuts the oblique rift. In the brittle mantle (strongest layer of the lithosphere), it prevents lateral propagation of the deformation along the rifted zone and localizes it along its boundaries, accumulating stresses. In particular, the stresses accumulate at the hardness inflection points, where the thinnest lithosphere is observed in the models. With ongoing rotation, the weakest part of the lithosphere would localize in these corners with a right-lateral shift, triggering the development of two independent spreading centers, allowing the development of a transform fault in between them. The presence of an additional oblique weakness would induce closer spreading centers and thus a shorter transform fault. 
These model observations are comparable with natural observations in the Gulf of Aden, where inherited Mesozoic basins seem to play an important role during Tertiary rifting: (1) In the Western Gulf of Aden, the deformation pattern is similar to models with an oblique weakness (model C) and to models with both oblique weakness and orthogonal hardness (model D) where Mesozoic basins are present. The fracture zones moderately affect the continental domain (e.g. KAFZ, $<100 \mathrm{~km}$ ), indicating relatively close spreading centers. (2) In the Eastern part, conversely, the deformation pattern is similar to models that ignore the oblique weakness zone [model A, Autin et al., 2010a] and to models with orthogonal hardness (model B) where Mesozoic basins are present. The fracture zones strongly affect the continental domain (e.g. AFFZ, >200 km), with widely spaced spreading centers. (3) This evolution could explain the strong asymmetry observed between the conjugate margins of the Eastern Gulf of Aden.

\section{Acknowledgments}

This study is a contribution due to GDR Marges, Actions Marges (Total, CNRS-INSU, Ifremer, BRGM), ANR YOCMAL, CNRS-INSU, Total, Ifremer and BRGM. We greatly thank F. Funiciello and C. Faccenna for their advices, comments, and help in the Laboratory of Experimental Geology of the University of Rome III. We also would like to thank D. Rossi for making available his rheological measurements. We thank G. Schreurs and an anonymous reviewer for their constructive comments and suggestions on the manuscript. Fig. 7 was produced with the GMT software package [Wessel and Smith, 1998].

\section{References}

Abelson, M., and A. Agnon (1997), Mechanics of oblique spreading and ridge segmentation, Earth and Planetary Science Letters, 148(3-4), 405-421, doi:10.1016/S0012821X(97)00054-X. 
D’ Acremont, E., S. Leroy, M. Maia, P. Gente, and J. Autin (2010), Volcanism, jump and propagation on the Sheba Ridge, eastern Gulf of Aden: Segmentation evolution and implications for accretion processes, Geophys. J. Int., 180, 535-551, doi: 10.1111/j.1365246X.2009.04448.x.

Agostini, A., G. Corti, A. Zeoli, and G. Mulugeta (2009), Evolution, pattern, and partitioning of deformation during oblique continental rifting: Inferences from lithospheric-scale centrifuge models, Geochem. Geophys. Geosyst., 10, 23 PP., doi:2009 10.1029/2009GC002676.

Andrew Samuel, M., N. Harbury, R. Bott, and A. Manan Thabet (1997), Field observations from the Socotran platform: their interpretation and correlation to Southern Oman, Marine and Petroleum Geology, 14(6), 661-673, doi:10.1016/S0264-8172(96)00033-5.

Armitage, J. J., J. S. Collier, and T. A. Minshull (2010), The importance of rift history for volcanic margin formation, Nature, 465(7300), 913-917, doi:10.1038/nature09063.

Audin, L., X. Quidelleur, E. Coulié, V. Courtillot, S. Gilder, I. Manighetti, P. Gillot, P. Tapponnier, and T. Kidane (2004), Paleomagnetism and K-Ar and 40Ar/39Ar ages in the Ali Sabieh area (Republic of Djibouti and Ethiopia): constraints on the mechanism of Aden ridge propagation into southeastern Afar during the last 10 Myr, Geophys. J. Int., 158, 327-345.

Autin, J. (2008), Déchirure continentale et segmentation du Golfe d'Aden Oriental en contexte de rifting oblique, $\mathrm{PhD}$ thesis, Université Paris VI, France.

Autin, J., N. Bellahsen, L. Husson, M.-O. Beslier, S. Leroy, and E. d' Acremont (2010a), Analog models of oblique rifting in a cold lithosphere, Tectonics, 29(6), TC6016, doi:10.1029/2010TC002671.

Autin, J., S. Leroy, M.-O. Beslier, E. d' Acremont, P. Razin, A. Ribodetti, N. Bellahsen, C. Robin, and K. Al Toubi (2010b), Continental break-up history of a deep magma-poor margin based on seismic reflection data (northeastern Gulf of Aden margin, offshore Oman), Geophys. J. Int., 180, 501-519, doi: 10.1111/j.1365-246X.2009.04424.x.

Bellahsen, N., and J. M. Daniel (2005), Fault reactivation control on normal fault growth: an experimental study, Journal of Structural Geology, 27(4), 769-780, doi:10.1016/j.jsg.2004.12.003.

Bellahsen, N., L. Husson, J. Autin, S. Leroy, and E. d' Acremont (this volume), The effect of thermal weakening and buoyancy forces on rift localization: Field evidences from the Gulf of Aden oblique rifting, Tectonophysics, Special Issue: The Gulf of Aden rift.

Bellahsen, N., C. Faccenna, F. Funiciello, J.-M. Daniel, and L. Jolivet (2003), Why did Arabia separate from Africa? Insights from 3-D laboratory experiments., Earth and Planetary Science Letters, 216, 365-381.

Bellahsen, N., M. Fournier, E. d' Acremont, S. Leroy, and J. M. Daniel (2006), Fault reactivation and rift localization: Northeastern Gulf of Aden margin, Tectonics, 25(1), TC1007, doi:10.1029/2004TC001626.

Benes, V., and P. Davy (1996), Modes of continental lithospheric extension: experimental verification of strain localization processes, Tectonophysics, 254(1-2), 69-87, doi:10.1016/0040-1951(95)00076-3.

Beydoun, Z. R., and H. R. Bichan (1969), The geology of Socotra Island, Gulf of Aden, J. Geol. Soc., 125, 413-441, doi:10.1144/gsjgs.125.1.0413.

Beydoun, Z. R., M. L. As-Saruri, and R. S. Baraba (1996), Sedimentary Basins of the Republic of Yemen : Their Structural Evolution and Geological Characteristics, Oil \& Gas Science and Technology, 51(6), 763-775, doi:10.2516/ogst:1996049.

Birse, A. C. R., W. F. Bott, J. Morrison, and M. A. Samuel (1997), The Mesozoic and early tertiary tectonic evolution of the Socotra area, eastern Gulf of Aden, Yemen, Marine and Petroleum Geology, 14(6), 675-684, doi:10.1016/S0264-8172(96)00043-8.

Bonini, M., T. Souriot, M. Boccaletti, and J.-P. Brun (1997), Successive orthogonal and 
oblique extension episodes in a rift zone: Laboratory experiments with application to the Ethiopian Rift, Tectonics, 16(2), 347-362.

Bott, W. f., B. a. Smith, G. Oakes, A. H. Sikander, and A. I. Ibraham (1992), The Tectonic Framework and Regional Hydrocarbon Prospectivity of the Gulf of Aden, Journal of Petroleum Geology, 15, 211-243., doi:10.1111/j.1747-5457.1992.tb00963.x.

Brannan, J., K. D. Gerdes, and I. R. Newth (1997), Tectono-stratigraphic development of the Qamar basin, eastern Yemen, Marine and Petroleum Geology, 14(6), 701-IN12, doi:10.1016/S0264-8172(96)00048-7.

Brun, J. P., and M. O. Beslier (1996), Mantle exhumation at passive margins, Earth and Planetary Science Letters, 142(1-2), 161-173, doi:10.1016/0012-821X(96)00080-5.

Brune, S., and J. Autin (this volume), Numerical experiments on oblique rifting: 3d lithospheric-scale models and the Gulf of Aden, Tectonophysics, Special Issue: The Gulf of Aden rift.

Brune, S., A. A. Popov, and S. V. Sobolev (2012), Modeling suggests that oblique extension facilitates rifting and continental break-up, J. Geophys. Res., 117(B8), B08402, doi:10.1029/2011JB008860.

Clifton, A. E., and R. W. Schlische (2001), Nucleation, growth, and linkage of faults in oblique rift zones: Results from experimental clay models and implications for maximum fault size, Geology, 29(5), 455-458, doi:10.1130/0091-7613.

Clifton, A. E., R. W. Schlische, M. O. Withjack, and R. V. Ackermann (2000), Influence of rift obliquity on fault-population systematics: results of experimental clay models, Journal of Structural Geology, 22(10), 1491-1509, doi:10.1016/S0191-8141(00)00043-2.

Corti, G. (2012), Evolution and characteristics of continental rifting: Analog modelinginspired view and comparison with examples from the East African Rift System, Tectonophysics, 522-523(0), 1-33, doi:10.1016/j.tecto.2011.06.010.

Corti, G., M. Bonini, F. Innocenti, P. Manetti, and G. Mulugeta (2001), Centrifuge models simulating magma emplacement during oblique rifting, Journal of Geodynamics, 31(5), 557576, doi:10.1016/S0264-3707(01)00032-1.

Corti, G., J. Van Wijk, M. Bonini, D. Sokoutis, S. Cloetingh, F. Innocenti, and P. Manetti (2003), Transition from continental break-up to punctiform seafloor spreading: How fast, symmetric and magmatic, Geophysical Research Letters, 30(12), n/a-n/a, doi:10.1029/2003GL017374.

Corti, G., E. Calignano, C. Petit, and F. Sani (2011), Controls of lithospheric structure and plate kinematics on rift architecture and evolution: An experimental modeling of the Baikal rift, Tectonics, 30(3), TC3011, doi:10.1029/2011TC002871.

D’Acremont, E., S. Leroy, M.-O. Beslier, N. Bellahsen, M. Fournier, C. Robin, M. Maia, and P. Gente (2005), Structure and evolution of the eastern Gulf of Aden conjugate margins from seismic reflection data, Geophysical Journal International, 160(3), 869-890, doi:10.1111/j.1365-246X.2005.02524.x.

D’Acremont, E., S. Leroy, M. Maia, P. Patriat, M.-O. Beslier, N. Bellahsen, M. Fournier, and P. Gente (2006), Structure and evolution of the eastern Gulf of Aden: insights from magnetic and gravity data (Encens-Sheba MD117 cruise), Geophysical Journal International, 165(3), 786-803, doi:10.1111/j.1365-246X.2006.02950.x.

Dauteuil, O., and J.-P. Brun (1993), Oblique rifting in a slow-spreading ridge, Nature, 361(6408), 145-148, doi:10.1038/361145a0.

Dauteuil, O., P. Huchon, F. Quemeneur, and T. Souriot (2001), Propagation of an oblique spreading center: the western Gulf of Aden, Tectonophysics, 332, 423- 442.

Davy, P., and P. R. Cobbold (1988), Indentation tectonics in nature and experiment. I: Experiments scaled for gravity, Bulletin of the Geological Institution of the University of Upsala, 14, 129-141. 
Davy, P., and P. R. Cobbold (1991), Experiments on shortening of a 4-layer model of the continental lithosphere, Tectonophysics, 188(1-2), 1-25, doi:10.1016/0040-1951(91)90311-F. Ebinger, C. J., and N. H. Sleep (1998), Cenozoic magmatism throughout east African resulting from impact of a single plume, Nature, 395, 788-791.

Ellis, A. C., H. M. Kerr, C. P. Cornwell, and D. O. Williams (1996), A tectono-stratigraphic framework for Yemen and its implications for hydrocarbon potential, Petroleum Geoscience, 2(1), 29-42, doi:10.1144/petgeo.2.1.29.

Fantozzi, P. L. (1996), Transition from continental to oceanic rifting in the Gulf of Aden: structural evidence from field mapping in Somalia and Yemen, Tectonophysics, 259(4), 285311.

Fournier, M., N. Bellahsen, O. Fabbri, and Y. Gunnell (2004), Oblique rifting and segmentation of the NE Gulf of Aden passive margin, Geochem. Geophys. Geosyst., 5(11), 24 p.

Fournier, M., P. Huchon, K. Khanbari, and S. Leroy (2007), Segmentation and along-strike asymmetry of the passive margin in Socotra, eastern Gulf of Aden: Are they controlled by detachment faults?, Geochemistry Geophysics Geosystems, 8(3).

Fournier, M. et al. (2010), Arabia-Somalia plate kinematics, evolution of the Aden-OwenCarlsberg triple junction, and opening of the Gulf of Aden, Journal of Geophysical Research: Solid Earth, 115(B4), n/a-n/a, doi:10.1029/2008JB006257.

George, R., N. Rogers, and S. Kelley (1998), Earliest magmatism in Ethiopia: Evidence for two mantle plumes in one flood basalt province, Geology, 26, 923-926.

Granath, J. W. (2001), The Nogal Rift of northern Somalia: Gulf of Aden. Reactivation of a Mesozoic Rift, Mémoires du Muséum national d'histoire naturelle, 186, 511-527.

Hofmann, C., V. Courtillot, G. Féraud, P. Rochette, E. Yirgu, E. Kefeto, and R. Pik (1997), Timing of the Ethiopian flood basalt event and implications for plume birth and global change., Nature, 389, 838-841.

Hubert-Ferrari, A., G. King, I. Manighetti, R. Armijo, B. Meyer, and P. Tapponnier (2003), Long-term elasticity in the continental lithosphere; modelling the Aden Ridge propagation and the Anatolian extrusion process, Geophysical Journal International, 153(1), 111-132, doi:10.1046/j.1365-246X.2003.01872.x.

Huchon, P., and K. Khanbari (2003), Rotation of the syn-rift stress field of the northern Gulf of Aden margin, Yemen, Tectonophysics, 364(3-4), 147-166.

Jestin, F., P. Huchon, and J. M. Gaulier (1994), The Somalia plate and the East African Rift System: present-day kinematics, Geophysical Journal International, 116(3), 637-654, doi:10.1111/j.1365-246X.1994.tb03286.x.

Kenea, N. H., C. J. Ebinger, and D. C. Rex (2001), Late Oligocene volcanism and extension in the southern Red Sea Hills, Sudan, Journal of the Geological Society of London, 158(Part 2), 285-294.

Khanbari, K. (2000), Propagation d'un rift océanique: Le Golfe d'Aden Ses effets structuraux sur la marge yéménite, PhD thesis, Laboratoire de Géologie, Ecole Normale Supérieure, Paris, France.

Kirby, S. H. (1983), Rheology of the lithosphere, Reviews of Geophysics, 21(6), 1458-1487, doi:10.1029/RG021i006p01458.

Lepvrier, C., M. Fournier, T. Bérard, and J. Roger (2002), Cenozoic extension in coastal Dhofar (southern Oman) : implications on the oblique rifting of the Gulf of Aden, Tectonophysics, 357, 279- 293.

Leroy, S. et al. (2004), From rifting to spreading in the eastern Gulf of Aden: a geophysical survey of a young oceanic basin from margin to margin, Terra Nova, 16, 185-192, doi:10.1111/j.1365-3121.2004.00550.x.

Leroy, S. et al. (2010a), Contrasted styles of rifting in the eastern Gulf of Aden: A combined 
wide-angle, multichannel seismic, and heat flow survey, Geochemistry Geophysics Geosystems, 11, Q07004, 1-14, doi:10.1029/2009GC002963.

Leroy, S., E. d' Acremont, C. Tiberi, C. Basuyau, J. Autin, F. Lucazeau, and H. Sloan (2010b), Recent off-axis volcanism in the eastern Gulf of Aden: Implications for plume-ridge interaction, Earth and Planetary Science Letters, 293(1-2), 140-153.

Leroy, S. et al. (2012), From rifting to oceanic spreading in the Gulf of Aden: a synthesis, Arabian Journal of Geosciences, 5, 859-901, doi:10.1007/s12517-011-0475-4.

Lucazeau, F., S. Leroy, F. Rolandone, E. d' Acremont, L. Watremez, A. Bonneville, B. Goutorbe, and D. Düsünur (2010), Heat-flow and hydrothermal circulation at the oceancontinent transition of the eastern gulf of Aden, Earth and Planetary Science Letters, 295(34), 554-570, doi:10.1016/j.epsl.2010.04.039.

Mart, Y., and O. Dauteuil (2000), Analogue experiments of propagation of oblique rifts, Tectonophysics, 316, 121-132.

McClay, K. R., and M. J. White (1995), Analogue modelling of orthogonal and oblique rifting, Marine and Petroleum Geology, 12(2), 137-151.

McKenzie, D. (1978), Some remarks on the development of sedimentary basins, Earth and Planetary Science Letters, 40, 25-42.

Menzies, M., and al (1994), Geology of the Republic of Yemen, in The Geology and Mineral Resources of Yemen, pp. 21-48.

Morrison, J., A. Birse, M. A. Samuel, S. M. Richardson, N. Harbury, and W. F. Bott (1997), The Cretaceous sequence stratigraphy of the Socotran platform, the Republic of Yemen, Marine and Petroleum Geology, 14(6), 685-699, doi:10.1016/S0264-8172(96)00042-6. Pérez-Gussinyé, M., and T. J. Reston (2001), Rheological evolution during extension at nonvolcanic rifted margins: Onset of serpentinization and development of detachments leading to continental breakup, J. Geophys. Res., 106(B3), 3961-3975.

Platel, J. P., and J. Roger (1989), Evolution dynamique du Dhofar (Sultanat d'Oman) pendant le Crétacé et le Tertiaire en relation avec l'ouverture du Golfe d'Aden, Bull. Soc. Geol. Fr., 8(2), 253-263.

Robinet, J., P. Razin, J. Serra-Kiel, A. Gallardo-Garcia, S. Leroy, J. Roger, and C. Grelaud (2013), The Paleogene pre-rift to syn-rift succession in the Dhofar margin (northeastern Gulf of Aden): Stratigraphy and depositional environments, Tectonophysics, doi:10.1016/j.tecto.2013.04.017.

Roger, J., J. P. Platel, C. Cavelier, and C. Bourdillonde-Grisac (1989), Données nouvelles sur la stratigraphie et l'histoire géologique du Dhofar (Sultanat d'Oman), Bull. Soc. Geol. Fr., 2, 265-277.

Roger, J., J. P. Platel, A. Berthiaux, and J. Le Métour (1992), Geological Map of Hawf with Explanatory Notes; sheet NE 39-16,

Rolandone, F., F. Lucazeau, S. Leroy, J.-C. Mareschal, R. Jorand, B. Goutorbe, and H.

Bouquerel (2013), New heat flow measurements in Oman and the thermal state of the Arabian shield and platform, Tectonophysics, (0), doi:10.1016/j.tecto.2012.12.034. [online] Available from: http://www.sciencedirect.com/science/article/pii/S0040195113000164 (Accessed 21 January 2013)

As-Saruri, M. A., R. Sorkhabi, and R. Baraba (2010), Sedimentary basins of Yemen: their tectonic development and lithostratigraphic cover, Arab J Geosci, 3(4), 515-527, doi:10.1007/s12517-010-0189-z.

Sokoutis, D., G. Corti, M. Bonini, J. Pierre Brun, S. Cloetingh, T. Mauduit, and P. Manetti (2007), Modelling the extension of heterogeneous hot lithosphere, Tectonophysics, 444(1-4), 63-79, doi:10.1016/j.tecto.2007.08.012.

Talwani, M., and O. Eldholm (1972), Continental Margin off Norway: A Geophysical Study, Geological Society of America Bulletin, 83(12), 3575-3606, doi:10.1130/0016-7606. 
Tron, V., and J. P. Brun (1991), Experiments on oblique rifting in brittle-ductile systems, Tectonophysics, 188, 71-84.

Vigny, C., P. Huchon, J. C. Ruegg, K. Khanbari, and L. M. Asfaw (2006), Confirmation of Arabia slow plate motion by new GPS data in Yemen, Journal of geophysical research, 111(B02402), doi:10.1029/2004JB003229.

Watchorn, F., G. J. Nichols, and D. W. J. Bosence (1998), Rift-related sedimentation and stratigraphy, southern Yemen (Gulf of Aden), in Sedimentation and Tectonics in Rift Basins: Red Sea-Gulf of Aden, edited by B. H. Purser and D. W. J. Bosence, pp. 165-189.

Watremez, L., S. Leroy, S. Rouzo, E. d' Acremont, P. Unternehr, C. Ebinger, F. Lucazeau, and A. Al-Lazki (2011), The crustal structure of the north-eastern Gulf of Aden continental margin: insights from wide-angle seismic data, Geophysical Journal International, 184(2), 575-594, doi:10.1111/j.1365-246X.2010.04881.x.

Wessel, P., and W. H. F. Smith (1998), New, improved version of generic mapping tools released, Eos, Transactions American Geophysical Union, 79(47), 579-579.

Van Wijk, J. W., and S. A. P. L. Cloetingh (2002), Basin migration caused by slow lithospheric extension, Earth and Planetary Science Letters, 198(3-4), 275-288, doi:10.1016/S0012-821X(02)00560-5.

Withjack, M. O., and W. R. Jamison (1986), Deformation produced by oblique rifting, Tectonophysics, 126(2-4), 99-124.

Wolfenden, E., C. Ebinger, G. Yirgu, A. Deino, and D. Ayalew (2004), Evolution of the northern Main Ethiopian rift: birth of a triple junction, Earth and Planetary Science Letters, 224(1-2), 213-228.

\section{Tables}

\begin{tabular}{|c|c|c|c|c|}
\hline & & & Nature & Model \\
\hline \multirow{3}{*}{ Crust } & \multirow{2}{*}{ Brittle upper crust } & Thickness & $20 \mathrm{~km}$ & $1.5 \mathrm{~cm}$ \\
\hline & & Density & $2.6-2.8 \mathrm{~g} . \mathrm{cm}^{-3}$ & $1.2 \mathrm{~g} \cdot \mathrm{cm}^{-3}$ \\
\hline & Ductile lower crust & $\begin{array}{c}\text { Thickness } \\
\text { Density } \\
\text { Viscosity }\end{array}$ & $\begin{array}{c}10 \mathrm{~km} \\
2.9 \mathrm{~g} . \mathrm{cm}^{-3} \\
10^{21} \mathrm{~Pa} . \mathrm{s}\end{array}$ & $\begin{array}{c}0.7 \mathrm{~cm} \\
1.25 \mathrm{~g} . \mathrm{cm}^{-3} \\
4.10^{4} \mathrm{~Pa} . \mathrm{s}\end{array}$ \\
\hline \multirow{5}{*}{ Mantle } & \multirow{2}{*}{$\begin{array}{l}\text { Lithospheric brittle } \\
\text { mantle }\end{array}$} & Thickness & $\sim 12 \mathrm{~km}$ & $0.8 \mathrm{~cm}$ \\
\hline & & Density & $3.3 \mathrm{~g} . \mathrm{cm}^{-3}$ & $1.2 \mathrm{~g} . \mathrm{cm}^{-3}$ \\
\hline & \multirow{3}{*}{$\begin{array}{l}\text { Lithospheric ductile } \\
\text { mantle }\end{array}$} & Thickness & $\sim 50 \mathrm{~km}$ & $2 \mathrm{~cm}$ \\
\hline & & Density & $3.3 \mathrm{~g} . \mathrm{cm}^{-3}$ & $1.33 \mathrm{~g} . \mathrm{cm}^{-3}$ \\
\hline & & Viscosity & $10^{23}$ Pa.s & 7.10 $0^{4}$ Pa.s \\
\hline & \multirow{2}{*}{ Asthenosphere } & Density & $3.2-3.4$ g.cm $\mathrm{cm}^{-3}$ & 1.41 g.cm $^{-3}$ \\
\hline & & Viscosity & $10^{19}$ Pa.s & $10 \mathrm{~Pa} . \mathrm{s}$ \\
\hline
\end{tabular}

Table 1: Main physical properties of natural and analog materials used in our models

\section{Figure captions}

Fig. 1: Reactivation of inherited Mesozoic basins in the Gulf of Aden [after Leroy et al., 
2012]. a) Possible schematic geometry of the main Mesozoic basins. b) Reactivation of the Mesozoic basins by the Tertiary rifting. Note the local en-échelon reactivation of the inherited basins and their systematic shift by fracture zones in their center. c) Present-day distribution of the reactivated basins along the conjugate margins of the Gulf of Aden. SSFZ: Shukra El Sheik Fracture Zone, KAFZ: Khanshir Al Irquah Fracture Zone, AFFZ: Alula-Fartak Fracture Zone.

Fig. 2: a) Deforming box used for the models whose size is initially $56 \times 30 \times 30 \mathrm{~cm}$. The different lengths of the drawer arms create two lateral discontinuities, imposing that the trend of deformation is overall oblique. The obliquity is either forced by the lateral discontinuities alone (boundaries-driven obliquity) or by the combination of lateral discontinuities with an oblique weakness (mainly reproducing an inherited obliquity). b) Strength profile for the experimental lithosphere, including both the oblique weakness and the orthogonal hardness. c) Experimental setup for the four models discussed in this study.

Fig. 3: Evolution of deformation in the brittle upper crust from surface views of the four models. It is noteworthy that the differences between models $\mathrm{C}$ and $\mathrm{D}$ are much more important than differences between models A and B. In other words, the mantle hardness (the inherited basin) has a stronger role in presence of an oblique inherited weakness.

Fig. 4: Evolution of the reactivated grabens (red dots) in models B (a) and D (b) with orthogonal inheritance. The final disposition of the reactivated grabens shows an enéchelon pattern in model $\mathrm{B}$, whereas it shows also alongside reactivated basins in model D. Thus, in oblique settings, the way inherited basins are reactivated is strongly dependent on the way obliquity is constrained.

Fig. 5: Evolution of the fault pattern in the brittle upper crust and of the oblique weakness and orthogonal inheritance for the 4 models.

Fig. 6: Comparison of deformation in the brittle upper crust and the brittle lithospheric 
mantle. a) Top of the brittle mantle at the end of the experiment. b) Thinned areas in the brittle upper crust (blue) and in the brittle mantle (orange) at the end of the experiment. Note the phase opposition of deformation in the crust and the mantle.

Fig. 7: Relative thickness of the most resistant layer in models B and D: the brittle mantle. Note that the highest thinned zones are localized on both sides of the inherited hardness and in particular close to the inflection points (circles).

Fig. 8: Two types of rift/ridge geometries in the Gulf of Aden [Bellahsen et al., this volume]. In the East, the Sheba ridge strikes parallel to long segments of the continental rifted margins $\left(110^{\circ} \mathrm{E}\right)$ and $\mathrm{OCT}$ and few (rather) large transform faults are active. In such a domain, the asthenosphere is rather cold and buoyancy forces were rather weak (but active) during rifting. In the West, the Aden ridge is highly segmented, with short segments, small and very numerous transform faults or accommodation zones between segments (same abbreviations as in Fig. 1). The ridge is parallel to the OCT $\left(070^{\circ} \mathrm{E}\right)$ but very oblique to the $\left(110^{\circ} \mathrm{E}\right.$ to $\left.140^{\circ} \mathrm{E}\right)$ syn-rift basins. This suggests strong active buoyancy forces due to a hotter asthenosphere than in the East, as a consequence of the nearby Afar hot spot activity.

Fig. 9: Comparison of model B with the Eastern Gulf of Aden. Right map from Leroy et al. [2012] based on a synthesis from field work and seismic reflection data [Beydoun and Bichan, 1969; Platel and Roger, 1989; Roger et al., 1989, 1992; Menzies and al, 1994; Fantozzi, 1996; Andrew Samuel et al., 1997; Morrison et al., 1997; Birse et al., 1997; Brannan et al., 1997; Watchorn et al., 1998; Khanbari, 2000; Lepvrier et al., 2002; Leroy et al., 2004, 2010a; Fournier et al., 2004; D’Acremont et al., 2005, 2006; Bellahsen et al., 2006; Autin et al., 2010b]. OCT: ocean continent transition. The 3 left figures are views of the model at the end of the experiment. The thinnest parts of the brittle mantle could lead, after rotation, to the initiation of shifted spreading centers on both side of the inherited 
hardness (OCT / future spreading centers of the Gulf of Aden are reported in red). This shift could be at the origin of the initiation of a transform fault. This evolution could explain the strong asymmetry of the conjugate margins in the Eastern Gulf of Aden. In our hypothesis, since the ridges localize close to the rift borders, it would also imply that (1) East of AFFZ, the largest distal continental domain is located on the Southern margin, between the OCT (red) and the Gardafui Basin; and (2) West of AFFZ, the northern distal margin should be wider, between the OCT and the Jiza-Qamar basin. 
a)

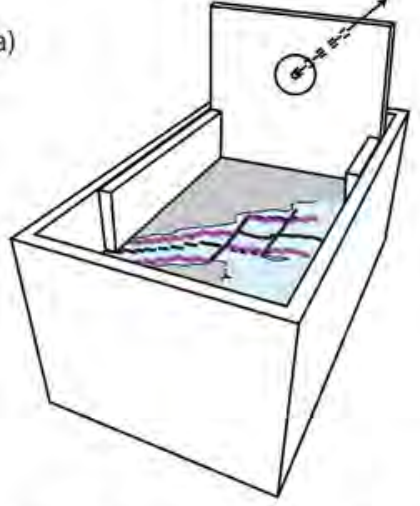

c)
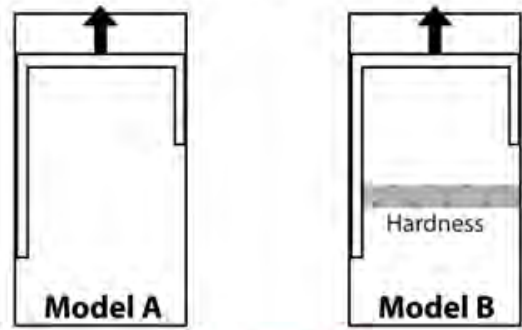

b)

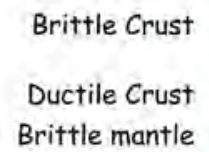

Ductile Mantle

Asthenosphere

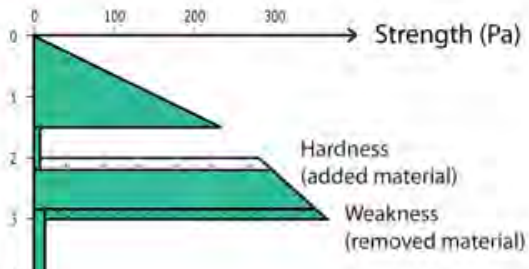

(removed material)

\section{Depth $(\mathrm{cm})$}
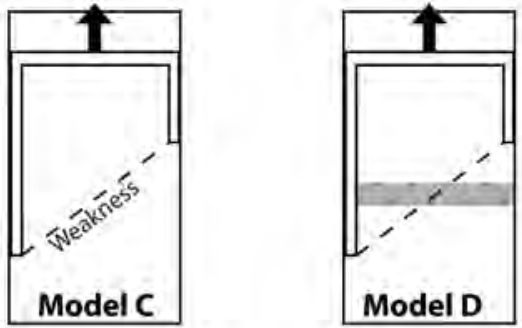

Strength profile of the normal lithosphere

Local strength profile in the center of each model
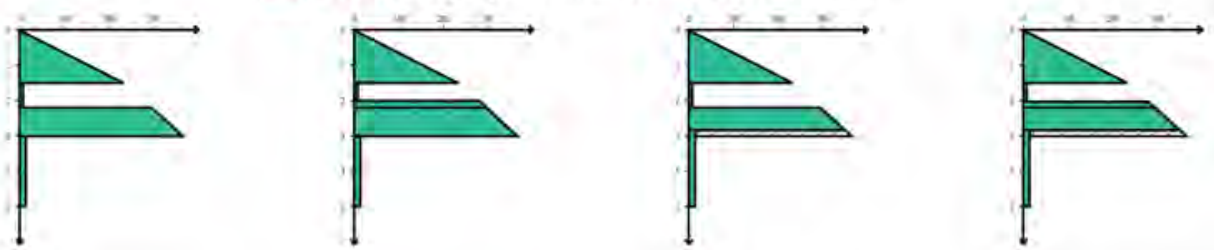


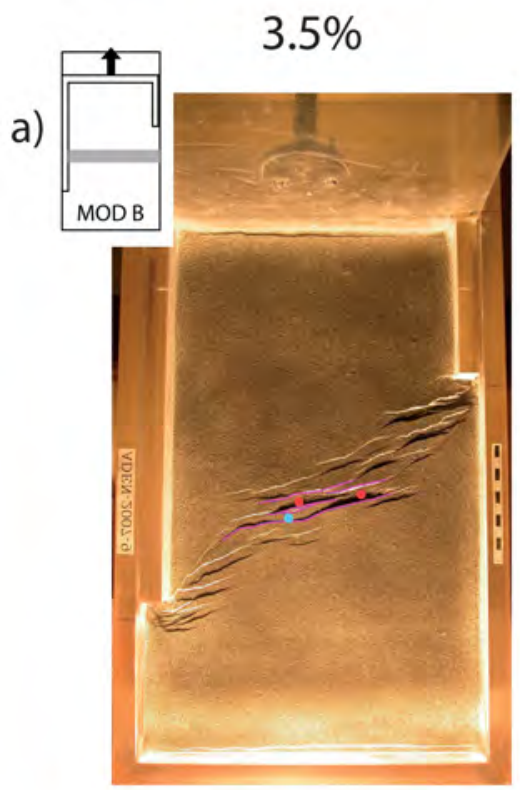

$13.5 \%$

$23 \%$

b)
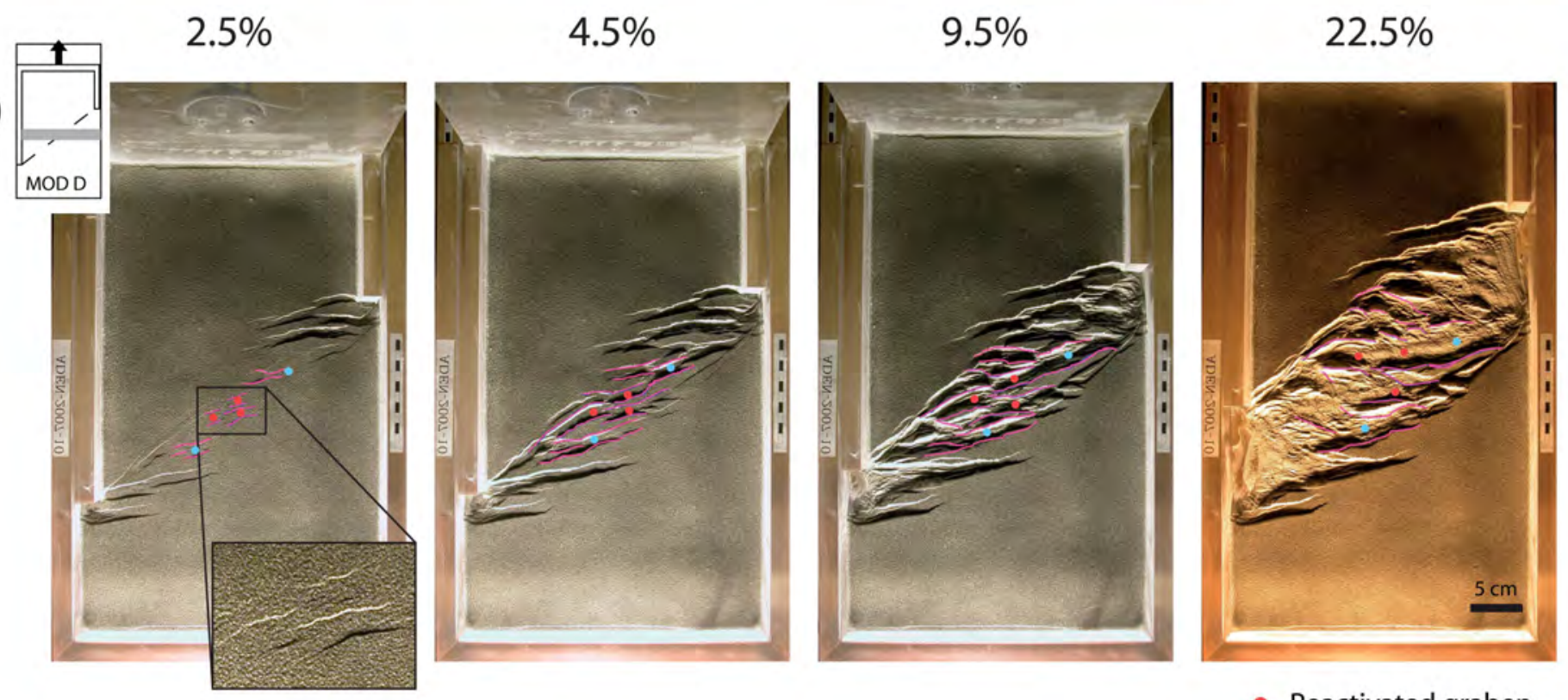

- Reactivated graben

- Neoformed graben 
a)
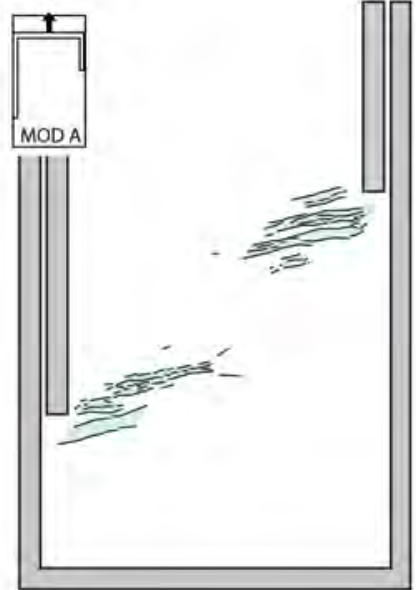

b)
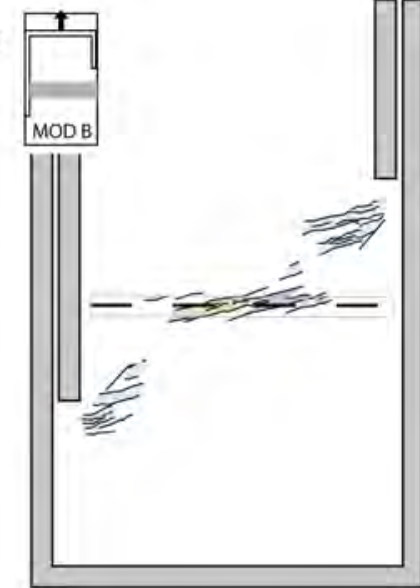

c)
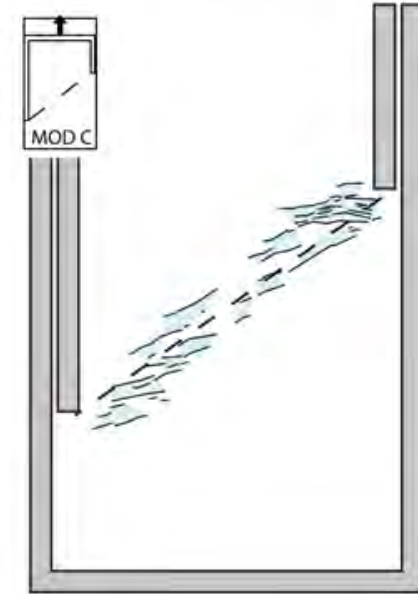

d)

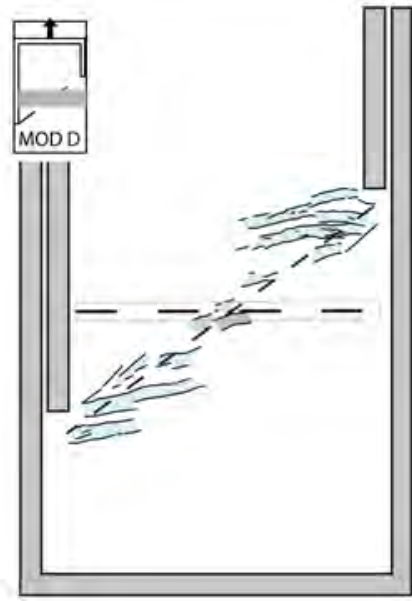

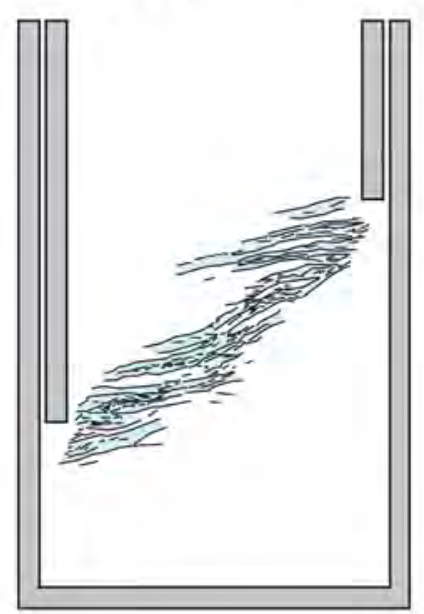
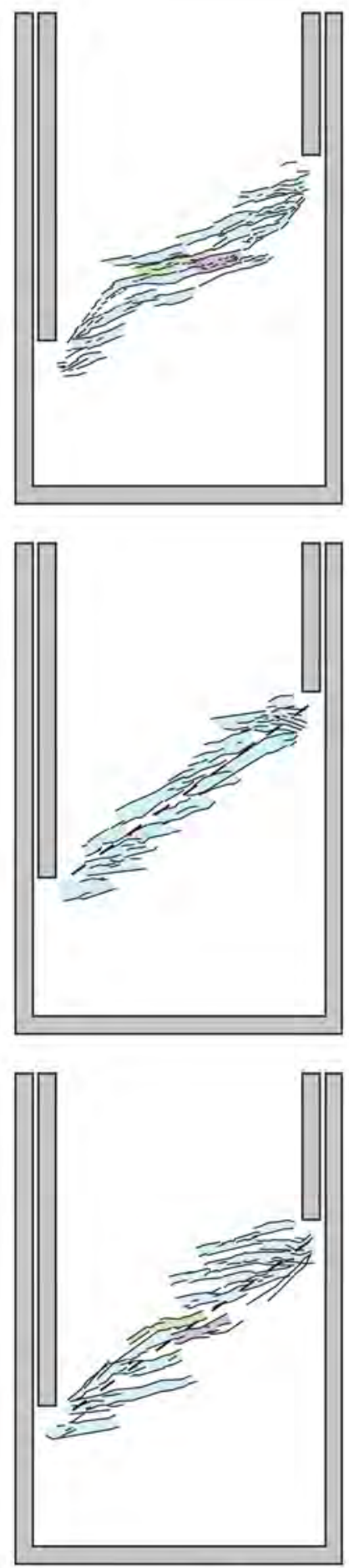

$=\quad$ Upper crustal faults

$\square$ Upper crust thinned areas Reactivated grabens

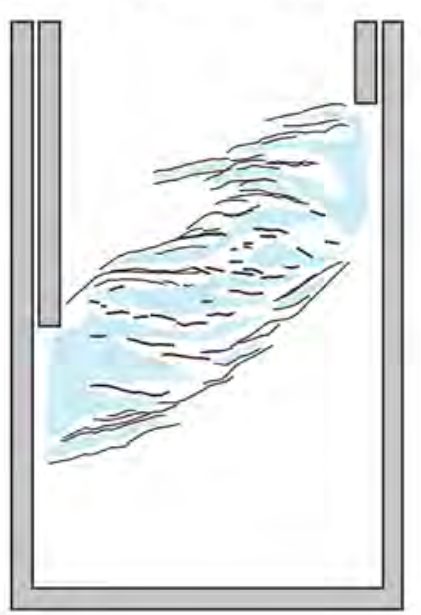

weakness
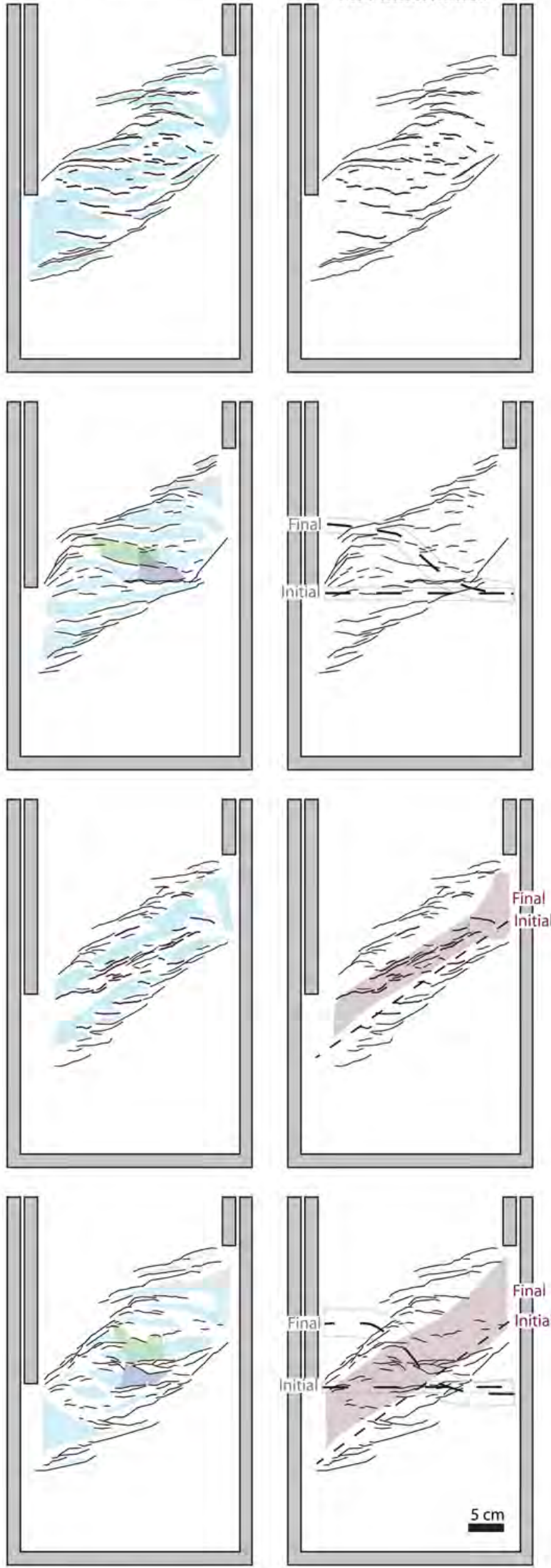

$\square$ Inheritance

$\square$ Initial oblique weakness

$\square$ Final stretched weakness 


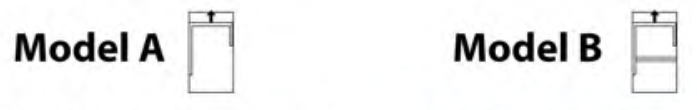

Model C

Model D

a) Thinned upper mantle at the end of experiment
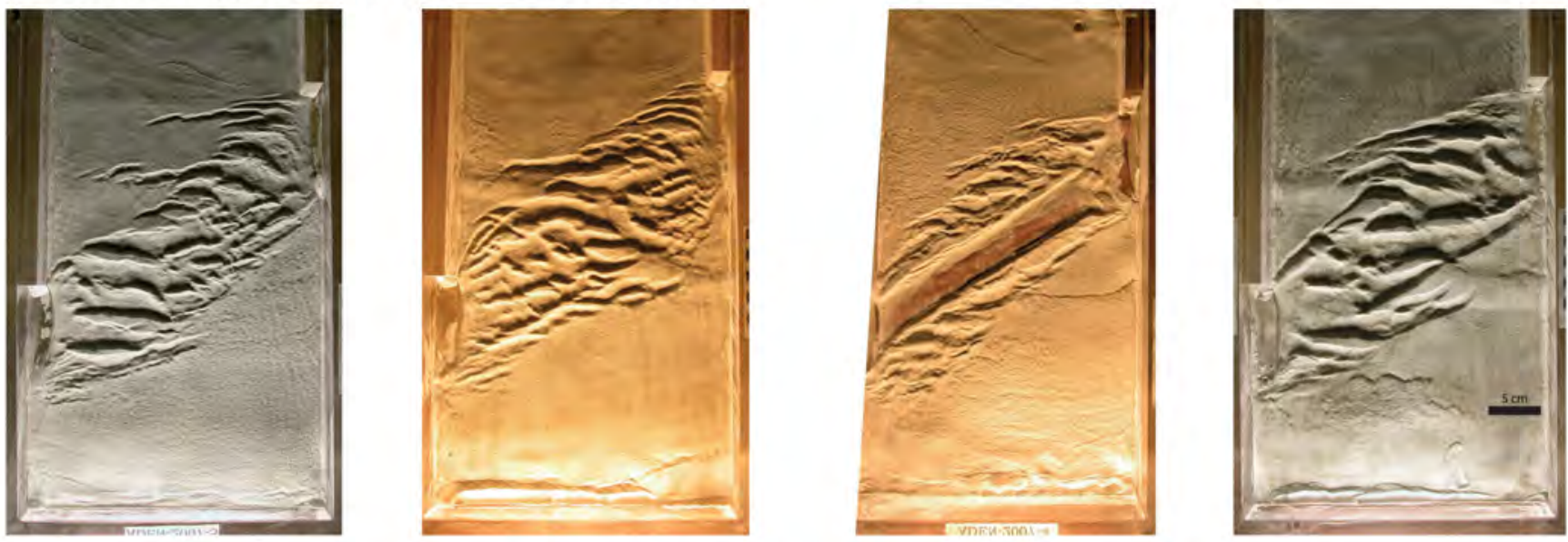

b) Brittle upper crust and brittle upper mantle at the end of experiment

Upper crust thinned areas

Upper mantle thinned areas
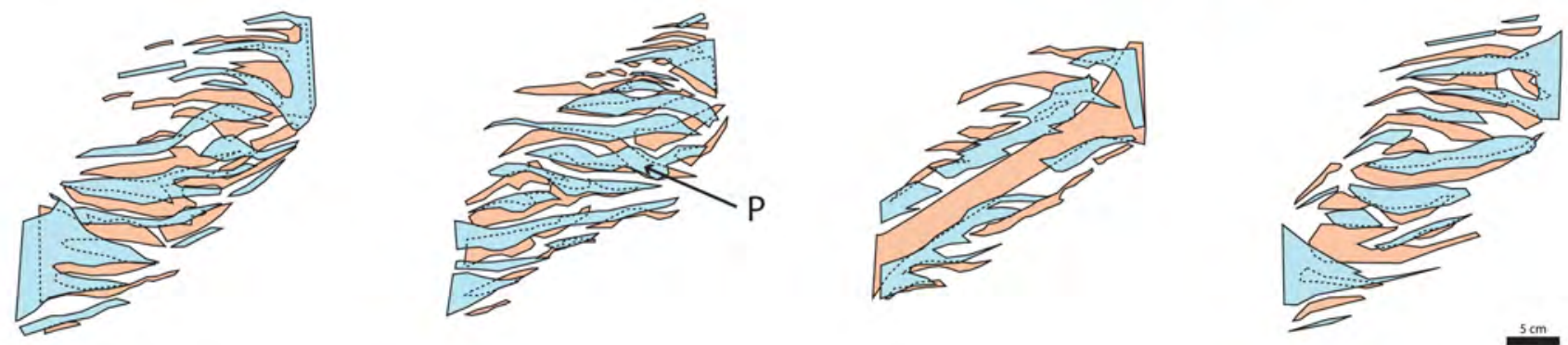
Whole crust thickness
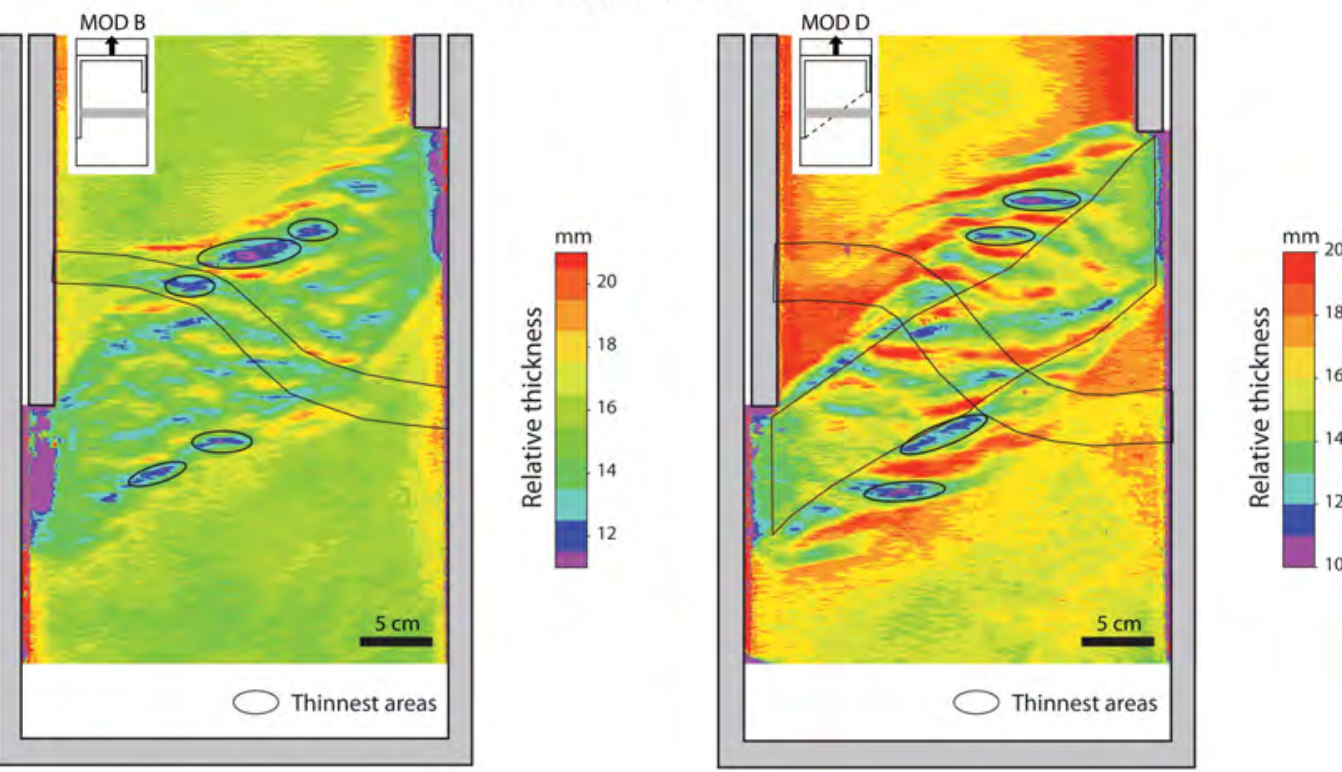

Brittle mantle thickness
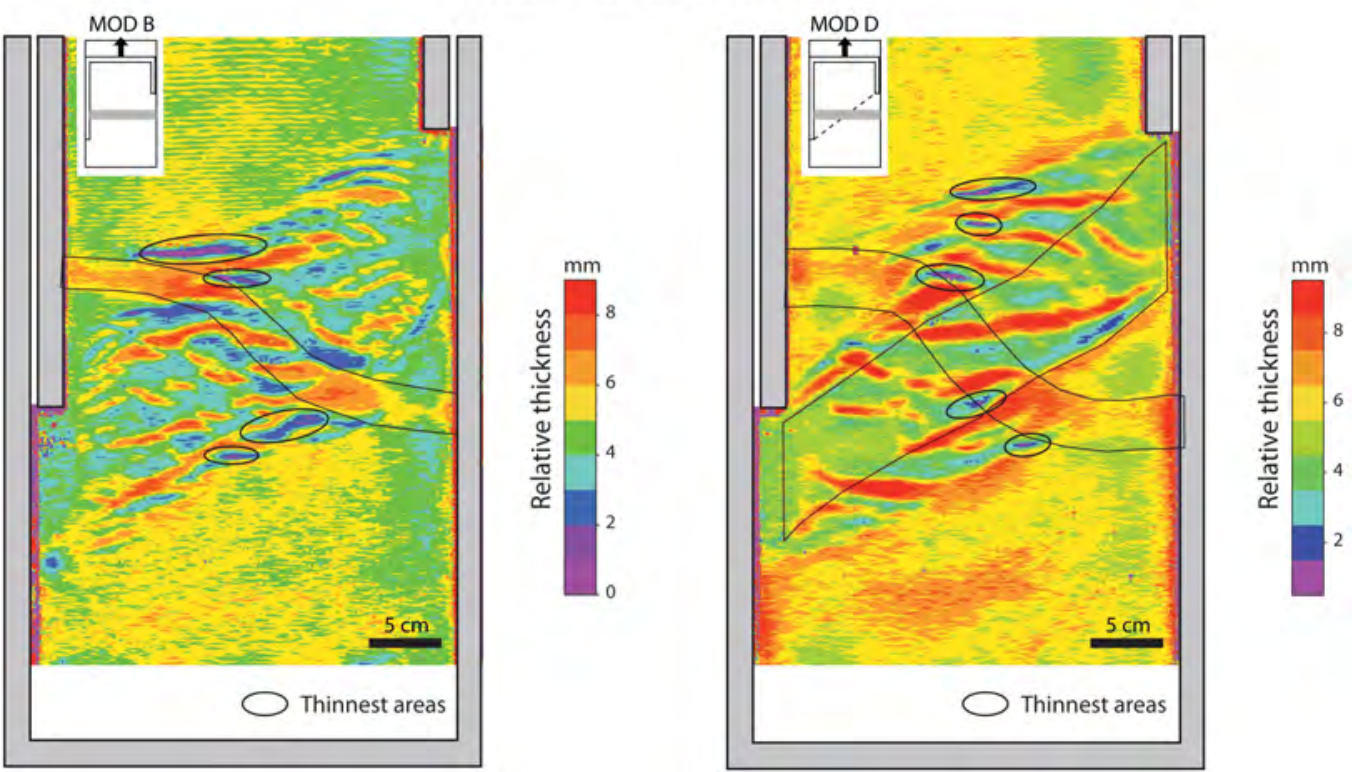


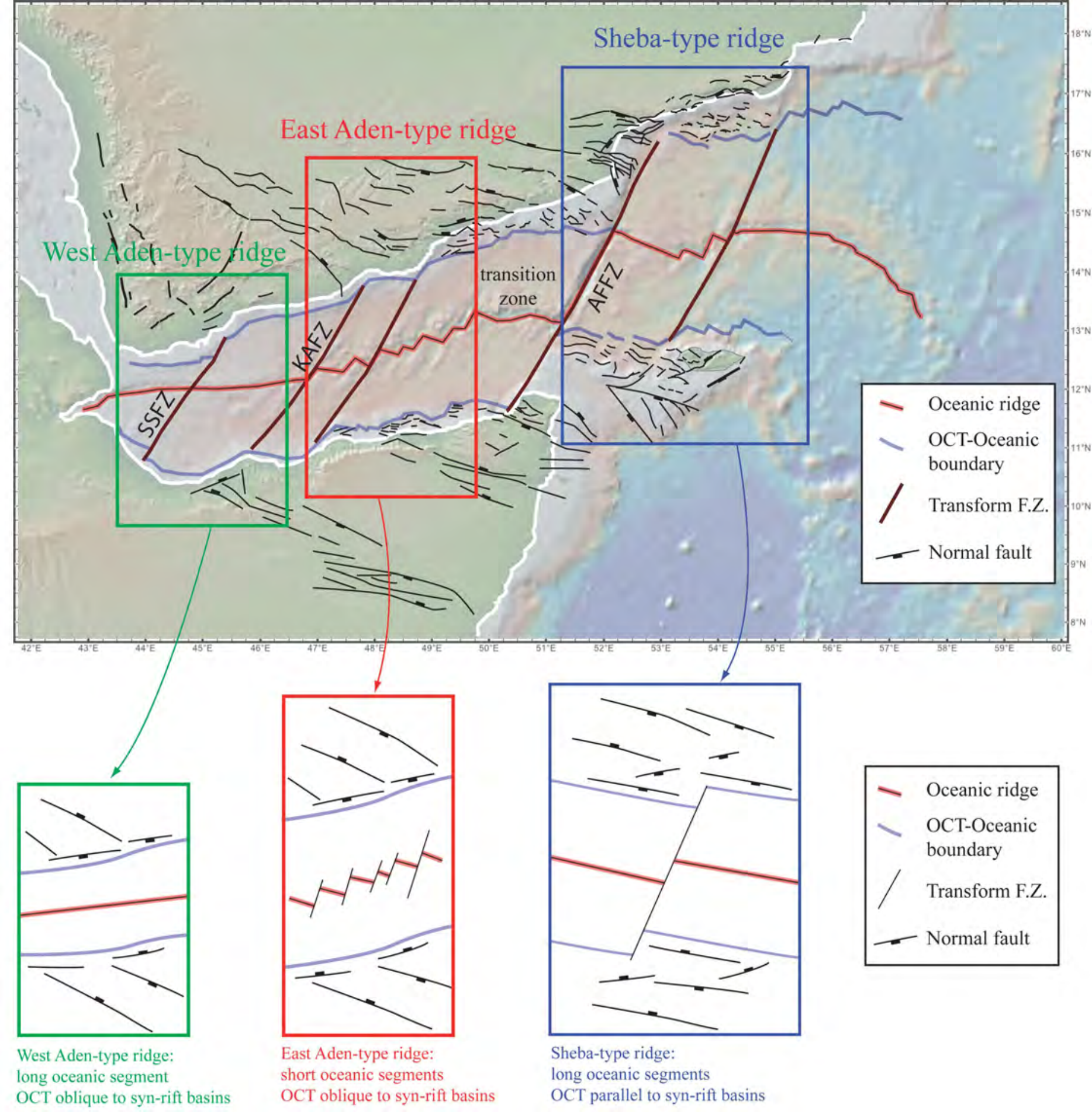


MODEL B

Reactivated basins

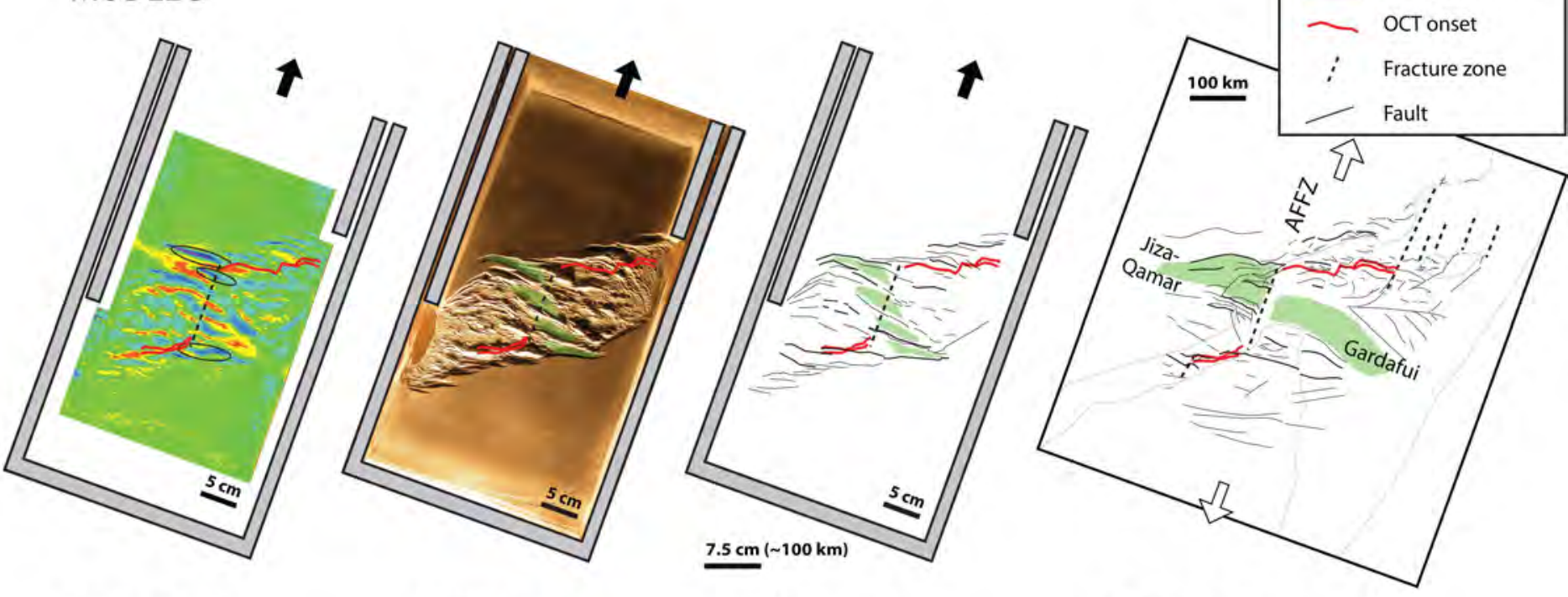

Brittle mantle thickness (Fig. 7)
Brittle crust

Main faults
Gulf of Aden at $\sim 20 \mathrm{Ma}$ (OCT onset) 